\title{
Organic agriculture supports biodiversity and sustainable food production
}

\author{
Authors: Teri Underwood, Christine McCullum- \\ Gomez, Alison H. Harmon, and Susan Roberts
}

This is an Accepted Manuscript of an article published in Journal of Hunger \& Environmental Nutrition on October 2011, available online:

http://www.tandfonline.com/10.1080/19320248.2011.627301.

Underwood, Teri, Christine McCullum-Gomez, Alison Harmon, and Susan Roberts. "Organic Agriculture Supports Biodiversity and Sustainable Food Production." Journal of Hunger \& Environmental Nutrition 6, no. 4 (October 2011): 398-423. doi:10.1080/19320248.2011.627301.

Made available through Montana State University's $\underline{\text { ScholarWorks }}$ scholarworks. montana.edu 


\title{
Organic Agriculture Supports Biodiversity and Sustainable Food Production
}

\author{
TERI UNDERWOOD, ${ }^{1}$ CHRISTINE MCCULLUM-GOMEZ, ${ }^{2}$ \\ ALISON HARMON, ${ }^{3}$ and SUSAN ROBERTS ${ }^{4}$ \\ ${ }^{1}$ Sustainable Diets, Park City, Utah \\ ${ }^{2}$ Houston, Texas \\ ${ }^{3}$ Food and Nutrition, Department of Health and Human Development, \\ Montana State University, Bozeman, Montana \\ ${ }^{4}$ Roberts Law Firm, PLC, Alkeny, Iowa
}

\begin{abstract}
Biodiversity is vital to several important ecosystem services that ensure sustainability of food production. In organic agriculture, land management practices that promote biodiversity and soil quality are emphasized and the goal is to maintain a sustainable agricultural system. Soil quality or soil bealth is the foundation for all agriculture and natural plant communities and a primary indicator of sustainable land management. Soil quality is affected by farm management and land use decisions. This article presents a review of the literature on the question: How do organic agriculture and conventional agriculture differ in regard to their impact on biodiversity and ecosystem services? All of the 22 articles identified in this review reported a significant increase in at least one variable that indicated enhanced biodiversity and/or ecosystem services on sites farmed using an organic farming system compared to sites farmed using a conventional farming system. This review underlines the importance of biodiversity, particularly soil biodiversity, to sustainable food production and underscores the need for further ecological studies on the links between farm management systems and soil quality.
\end{abstract}

KEYWORDS sustainable food systems, sustainable agriculture, biodiversity, ecosystem services, organic food, organic agriculture

Address correspondence to Teri Underwood, President, Sustainable Diets, 9475 Silvercreek Rd., Park City, UT 84098. E-mail: teriunderwood@earthlink.net 


\section{INTRODUCTION AND PURPOSE}

Today's farmers produce more food and fiber with less energy than farmers did 50 years ago. ${ }^{1}$ However, there is concern that conventional agriculture is not sustainable due to its dependence on nonrenewable, external inputs such as chemical fertilizers and pesticides and its poor regeneration of soil, groundwater, and other natural resources on which agricultural production depends. ${ }^{2,3}$ Conventional agriculture also contributes to numerous ecological and environmental problems, such as ground- and surface water pollution ${ }^{4-6}$; reduction in key pollinators of food $\operatorname{crops}^{5,7,8}$; distortion in relative-abundance distributions of natural enemy communities in favor of a few dominant species ${ }^{9,10}$; potential human health risks from exposure to agricultural chemicals ${ }^{2,11-18}$; potential human health risks associated with contamination of food and water ${ }^{2,11,19-24}$; chemical and physical soil degradation ${ }^{2,3-5,25}$; and significant declines in global biodiversity. ${ }^{26-31}$

\section{Biodiversity, Ecosystem Services, and Sustainable Agriculture}

Human survival and agriculture are dependent on a variety of goods and services that ecosystems provide. Food and fiber production, soil formation, pollination of food crops, suppression of infectious disease, regulation of agricultural pests, water purification, nutrient cycling, and climate regulation are examples of ecosystem services vital to human health and agriculture. ${ }^{32-38}$ Yet, according to the United Nations Millennium Ecosystem Assessment (MEA), approximately 60\% of the ecosystem services examined from air quality to water purification are being degraded or used unsustainably. ${ }^{26}$ See Table 1 for definitions related to biodiversity and ecosystem services.

Biodiversity is central to ecosystem function and the provision of ecosystem services. ${ }^{33}$ Yet today global biodiversity is plummeting, with current extinction rates 100 to 1000 times that seen in the fossil record. ${ }^{38}$ The loss of global biodiversity to meet growing demands for food, water, timber, and fuel has impaired ecosystem function and resulted in a decline in ecosystem services. ${ }^{26,33}$

Agroecosystems cover $40 \%$ of the terrestrial surface of the Earth and differ radically in how they are managed. ${ }^{8}$ Farm management practices can degrade biodiversity. ${ }^{39,40}$ For example, the use of synthetic fertilizers in agriculture has led to eutrophication and a decline in aquatic biodiversity and freshwater resources. ${ }^{26}$ The MEA concluded that agriculture is the "largest threat to biodiversity and ecosystem function of any single human activity." 35 (p. 777)

Global biodiversity decline has substantial implications for human health and sustainable agriculture. Biodiversity is essential to several ecosystem services needed for agriculture and the provision of food, such as soil formation, nutrient cycling, and pollination of crops. ${ }^{8,26,27,33,34}$ The 
TABLE 1 Definitions of Key Terms

\begin{tabular}{|c|c|}
\hline Key terms & Definitions \\
\hline $\begin{array}{l}\text { Agroeco- } \\
\text { system }\end{array}$ & $\begin{array}{l}\text { An ecosystem designed and managed by humans to produce agricultural } \\
\text { goods }\end{array}$ \\
\hline Biomass & $\begin{array}{l}\text { The total mass of living biological material present in a given ecosystem at a } \\
\text { certain time }\end{array}$ \\
\hline $\begin{array}{l}\text { Biological } \\
\text { soil } \\
\text { degradation }\end{array}$ & $\begin{array}{l}\text { A decline in biodiversity and soil carbon and an increase in soil-borne } \\
\text { pathogens. See also soil degradation (below) })^{2,42}\end{array}$ \\
\hline Biodiversity & $\begin{array}{l}\text { The variety and variability of life at different levels of biological organization, } \\
\text { such as the genetic, species, and ecosystem levels }{ }^{43}\end{array}$ \\
\hline \multirow[t]{3}{*}{$\begin{array}{l}\text { Carbon } \\
\text { markets }\end{array}$} & $\begin{array}{l}\text { A market (voluntary or mandatory) that is created from the trading of carbon } \\
\text { emission allowances to encourage or help countries and companies to } \\
\text { limit their carbon dioxide }\left(\mathrm{CO}_{2}\right) \text { emissions, reducing greenhouse } \\
\text { gases }^{44}\end{array}$ \\
\hline & $\begin{array}{l}\text { In a cap and trade system a limit (cap) is set on } \mathrm{CO}_{2} \text { emissions and permits } \\
\text { are given to emitters to release a certain amount of } \mathrm{CO}_{2} \text {. If a company } \\
\text { exceeds its allowance, it has to purchase additional permits to cover the } \\
\text { excess. If a company does not exceed its limit, then it can sell its unused } \\
\text { allowances }\end{array}$ \\
\hline & $\begin{array}{l}\text { Agriculture can offset greenhouse gas emissions by increasing the capacity } \\
\text { for carbon uptake and storage in soils; that is, carbon sequestration }\end{array}$ \\
\hline $\begin{array}{l}\text { Decomposi- } \\
\text { tion }\end{array}$ & $\begin{array}{l}\text { The breakdown of plant material carried out by bacteria and fungi resulting } \\
\text { in the release of energy, nutrients, and } \mathrm{CO}_{2}^{8}\end{array}$ \\
\hline Ecosystem & $\begin{array}{l}\text { A dynamic complex of plant, animal, and microorganism communities and } \\
\text { the non-living physical environment interacting as a functional unit. } \\
\text { Ecosystems include physical and chemical components such as soils, } \\
\text { waters, and nutrients that support the organisms living within them and } \\
\text { interactions among all organisms in a given habitat. The health and } \\
\text { well-being of human populations depend upon the services provided by } \\
\text { ecosystems and their components-including organisms, soil, water, and }_{\text {nutrients }^{32}}\end{array}$ \\
\hline $\begin{array}{l}\text { Ecosystem } \\
\text { function, } \\
\text { function- } \\
\text { ing, or } \\
\text { process }\end{array}$ & $\begin{array}{l}\text { Biogeochemical activities of ecosystems. The most common metric of } \\
\text { ecosystem functioning is primary production, but other metrics including } \\
\text { decomposition, nutrient mineralization, community or ecosystem } \\
\text { respiration, or other measures of energy flow and nutrient cycling. } \\
\text { Function refers to activity, not purpose }{ }^{36}\end{array}$ \\
\hline $\begin{array}{l}\text { Ecosystem } \\
\text { services }\end{array}$ & $\begin{array}{l}\text { The services that the Earth's ecosystems provide man, such as food and fiber } \\
\text { provision, soil fertility, water purification, disease management, climate } \\
\text { regulation, spiritual fulfillment, and aesthetic enjoyment. These services are } \\
\text { extensive and diverse and affect the quality of our land, water, food, and } \\
\text { health. In agroecosystems, biodiversity performs a myriad of essential } \\
\text { ecosystem services beyond the production of food and fiber, including } \\
\text { nutrient cycling into food crops; generation and preservation of soils and } \\
\text { renewing soil fertility; climate moderation (control); resilience to drought; } \\
\text { pest control; and provision of habitat for beneficial insects, such } \\
\text { pollinators, decomposers, and predators }\end{array}$ \\
\hline Humus & $\begin{array}{l}\text { The final product of soil organic matter decomposition. It is highly stable } \\
\text { and a vital component of soil fertility. Humus participates in soil formation } \\
\text { and quality maintenance through its specific properties; for example, } \\
\text { carbon retention, water retention, and stabilization of soil aggregates. } \\
\text { Humus is an important buffer, reducing fluctuations in soil acidity and } \\
\text { nutrient availability }{ }^{37}\end{array}$ \\
\hline
\end{tabular}


TABLE 1 (Continued)

\begin{tabular}{|c|c|}
\hline Key terms & Definitions \\
\hline $\begin{array}{l}\text { Intensive or } \\
\text { conven- } \\
\text { tional } \\
\text { agriculture }\end{array}$ & $\begin{array}{l}\text { An agriculture production system using high inputs of resources relative to } \\
\text { land area for the purpose of increasing crop yield. This is accomplished } \\
\text { through a variety of technological methods such as the use of } \\
\text { high-yielding or genetically modified crop varieties, synthetic fertilizers, } \\
\text { pesticide application, artificial irrigation, monocropping, heavy tilling, and } \\
\text { mechanization? }\end{array}$ \\
\hline $\begin{array}{l}\text { Microbial } \\
\text { biomass }\end{array}$ & $\begin{array}{l}\text { The living portion of soil organic matter. It contains archaea, bacteria, and } \\
\text { eukaryotes, excluding roots and animals smaller than } 5 \times 10^{3} \mu \mathrm{m}^{3} \text {. } \\
\text { It represents } 75 \% \text { to } 98 \% \text { of the living portion of the soil }{ }^{45}\end{array}$ \\
\hline $\begin{array}{l}\text { Millennium } \\
\text { Ecosystem } \\
\text { Assessment }\end{array}$ & $\begin{array}{l}\text { A United nation's-sponsored assessment carried out to assess the } \\
\text { consequences of ecosystem change for human well-being and to establish } \\
\text { the scientific basis for actions needed to enhance the conservation and } \\
\text { sustainable use of ecosystems. The assessment was conducted by an } \\
\text { international group of over } 1300 \text { scientific and ecological experts from } \\
2001 \text { to } 2005^{26}\end{array}$ \\
\hline Mycorrhizae & $\begin{array}{l}\text { A relationship of symbiosis between the roots of most higher plants and } \\
\text { several groups of fungi, in which the fungal partner typically derives } \\
\text { energy from the plant and the plant receives nutrients from the fungus }\end{array}$ \\
\hline $\begin{array}{l}\text { Natural } \\
\text { enemy }\end{array}$ & $\begin{array}{l}\text { A predator, parasite, parasitoid, or pathogen of another organism; often } \\
\text { describes beneficial organisms that attack pests in agricultural } \\
\text { systems }^{8}\end{array}$ \\
\hline $\begin{array}{l}\text { Nutrient } \\
\text { cycling }\end{array}$ & $\begin{array}{l}\text { Nutrients are elements such as nitrogen, carbon, oxygen, water, sulfur, } \\
\text { magnesium, potassium, and phosphorus that are required for the growth } \\
\text { of plants and most all organisms. Nutrients move locally, regionally, and } \\
\text { globally from the physical environment into living organisms and back } \\
\text { again }{ }^{37}\end{array}$ \\
\hline \multirow[t]{3}{*}{$\begin{array}{l}\text { Organic } \\
\text { production/ } \\
\text { agriculture }\end{array}$} & $\begin{array}{l}\text { The USDA National Organic Program defines organic production as an } \\
\text { ecological production system, established to respond to site-specific } \\
\text { conditions by integrating cultural, biological, and mechanical practices that } \\
\text { foster cycling of resources, promote ecological balance, and conserve } \\
\text { biodiversity. }{ }^{46,47,48} \text { As such, organic crop producers use practices that aim } \\
\text { to maintain or improve the physical, chemical, or biological condition of } \\
\text { soil, minimizing soil erosion and accommodating an animal's natural } \\
\text { nutritional and behavioral requirements. }{ }^{48}\end{array}$ \\
\hline & $\begin{array}{l}\text { The World Health Organization (WHO) defines organic agriculture as a } \\
\text { holistic production management system that promotes and enhances } \\
\text { agroecosystem health, including biodiversity, biological cycles, and soil } \\
\text { biological activity. It emphasizes the use of management practices in } \\
\text { preference to the use of off-farm inputs, taking into account that regional } \\
\text { conditions require locally adapted systems. This is accomplished by using, } \\
\text { where possible, cultural, biological, and mechanical methods, as opposed } \\
\text { to using synthetic materials, to fulfill any specific function within the } \\
\text { system. }\end{array}$ \\
\hline & $\begin{array}{l}\text { The IFOAM defines organic agriculture as a production system that sustains } \\
\text { the health of soils, ecosystems, and people. It relies on ecological } \\
\text { processes, biodiversity, and cycles adapted to local conditions, rather than } \\
\text { the use of inputs with adverse effects. Organic agriculture combines } \\
\text { tradition, innovation, and science to benefit the shared environment and } \\
\text { promote fair relationships and a good quality of life for all } \\
\text { involved }\end{array}$ \\
\hline
\end{tabular}


TABLE 1 (Continued)

\begin{tabular}{|c|c|}
\hline Key terms & Definitions \\
\hline Resilience & $\begin{array}{l}\text { The ability of an ecosystem to recover from or resist disturbances and } \\
\text { perturbation, so that the key components and processes of the system } \\
\text { remain the same }\end{array}$ \\
\hline $\begin{array}{l}\text { Soil } \\
\text { biodiversity }\end{array}$ & $\begin{array}{l}\text { The variation in soil life, from genes to communities, and the variation in soil } \\
\text { habitats, from micro-aggregates to entire landscapes }{ }^{37}\end{array}$ \\
\hline $\begin{array}{l}\text { Soil (biota) } \\
\text { biomass }\end{array}$ & See microbial biomass \\
\hline Soil biota & $\begin{array}{l}\text { A collective term for all organisms living in the soil, including bacteria, } \\
\text { nematodes, fungal mycelium, protozoans, earthworms, and arthropods. } \\
\text { Soil biota also include the living plant roots that grow in the soil and } \\
\text { interact with other species above and below ground. }{ }^{43} \text { Soil biota maintains } \\
\text { soil fertility and mediates several key ecosystem services important to } \\
\text { agriculture including nutrient cycling and soil organic matter formation }{ }^{38}\end{array}$ \\
\hline $\begin{array}{l}\text { Soil } \\
\text { degradation }\end{array}$ & $\begin{array}{l}\text { The decline in soil quality or a reduction in its productivity and } \\
\text { environmental regulatory capacity. Three principal processes of soil } \\
\text { degradation are chemical (eg, salinization or nutrient depletion), physical } \\
\text { (eg, compaction or reduction in water-holding capacity), and biological } \\
\text { (eg, reduction in soil organic carbon or soil biodiversity) }\end{array}$ \\
\hline Soil fertility & $\begin{array}{l}\text { The quality of a soil that enables it to provide nutrients in adequate amounts } \\
\text { and in proper balance for the growth of specified plants or crops }{ }^{52}\end{array}$ \\
\hline $\begin{array}{l}\text { Soil organic } \\
\text { matter } \\
(\mathrm{SOM})\end{array}$ & $\begin{array}{l}\text { Any component of the soil that contains carbon compounds from living } \\
\text { organisms. SOM is mostly dead or decaying plants (up to } 85 \% \text { ); living roots } \\
\text { and soil organisms make up the remainder. }{ }^{37} \text { SOM is an important building } \\
\text { block for the soil structure, contributing to soil aeration and enabling soil } \\
\text { to absorb water and retain nutrients. }\end{array}$ \\
\hline & $\begin{array}{l}\text { Approximately half of SOM can be decomposed into its elemental form (the } \\
\text { active soil organic matter), whereas the remaining fraction, also known as } \\
\text { humus, is more resistant to composition and accumulates in soil (the } \\
\text { inactive SOM) }\end{array}$ \\
\hline Soil quality & $\begin{array}{l}\text { The capacity of a specific kind of soil to function, within natural or managed } \\
\text { ecosystem boundaries, to sustain plant and animal productivity, maintain } \\
\text { or enhance water and air quality, and support human health and } \\
\text { habitation }{ }^{43,53}\end{array}$ \\
\hline $\begin{array}{l}\text { Species } \\
\text { richness }\end{array}$ & $\begin{array}{l}\text { 1. The number of species in a community, in a landscape or marinescape, or } \\
\text { in a region. } 2 \text {. Having a relatively large diversity of species in a given } \\
\text { ecosystem }{ }^{41}\end{array}$ \\
\hline Sustainability & $\begin{array}{l}\text { Meeting the needs of the present without compromising the ability of future } \\
\text { generations to meet their needs }\end{array}$ \\
\hline $\begin{array}{l}\text { Sustainable } \\
\text { agriculture }\end{array}$ & $\begin{array}{l}\text { An integrated system of plant and animal production practices having a } \\
\text { site-specific application that will, over the long term:satisfy human food } \\
\text { and fiber needs;enhance environmental quality and the natural resource } \\
\text { base upon which the agricultural economy depends;make the most } \\
\text { efficient use of nonrenewable resources and on-farm resources and } \\
\text { integrates, where appropriate, natural biological cycles and controls; } \\
\text { sustains the economic viability of farm operations; andenhance the quality } \\
\text { of life for farmers and society as a whole }\end{array}$ \\
\hline $\begin{array}{l}\text { Systems } \\
\text { thinking }\end{array}$ & $\begin{array}{l}\text { Critical thinking that recognizes the importance of interconnections and } \\
\text { functional relationships between different components of the farming } \\
\text { system, }{ }^{2} \text { such as soils, plants, insects, fungi, animals, and water }\end{array}$ \\
\hline Taxon & $\begin{array}{l}\text { A group of (one or more) organisms that a taxonomist adjudges to be a } \\
\text { unit. }{ }^{37} \text { Taxa is plural for taxon }\end{array}$ \\
\hline
\end{tabular}


FIGURE 1 Conceptual model linking biodiversity to human well-being. ${ }^{36}$

relationship between biodiversity, ecosystem services, and human wellbeing can be summarized by a simple formula, ${ }^{36}$ which is outlined in Figure 1.

Conservation of biodiversity is recognized by scientists and practitioners as an important element of sustainable agriculture. Numerous studies and practical experiences have shown that biodiversity contributes to the resilience and stability of farming systems. ${ }^{2}$ Concerns about the detrimental effects of intensive agriculture practices, ${ }^{2,25,37,38}$ such as chemical soil degradation from the use of pesticides and excessive fertilization, ${ }^{2}$ have led to the development of sustainable agricultural systems, including organic agriculture. ${ }^{55}$ A systems approach and integrated management strategies that seek to enhance biodiversity, soil quality, and ecosystem services is fundamental to the practice of organic agriculture. ${ }^{8}$ See Table 1 for multiple, internationally recognized definitions related to organic production and organic agriculture.

The purpose of this review is to examine (1) how organic agriculture differs from conventional agriculture in regard to its impact on biodiversity and ecosystem services and (2) the implications of organic agriculture on soil quality, sustainable agriculture, and human health.

\section{Soil Biodiversity}

It is estimated that soil contains one fourth of all of the biodiversity on Earth. ${ }^{37}$ According to the Food and Agriculture Organization of the United Nations (FAO), "Soil is one of nature's most complex ecosystems: it contains thousands of different organisms, which interact and contribute to the global cycles that make all life possible." ${ }^{43(\mathrm{p} 15)}$ Collectively referred to as soil biodiversity, algae, bacteria, fungi, insects, and other soil organisms are interdependent in a complex food web., ${ }^{2,37}$

The rich biodiversity in soil provides a number of important ecosystem services essential to human health and agriculture. These services fall into 6 categories: (1) maintenance of soil structure, soil organic matter (SOM), and fertility; (2) regulation of carbon flux and climate via carbon storage; (3) water cycle regulation; (4) decontamination and bioremediation; (5) pest control; and (6) human health. ${ }^{37}$

In summary:

1. Soil is a diverse ecosystem of life that performs several services important to agriculture and the provision of food and 
2. Soil biodiversity is crucial to soil ecosystem function and the provision of ecosystem services. ${ }^{37}$

Soil Quality

Soil quality or soil health is the foundation for all agriculture and natural plant communities and is a primary indicator of sustainable land management. ${ }^{56}$ In this article, soil health and soil quality are used synonymously and imply soil that is productive and capable of supporting plant growth and normal ecosystem functioning.

Soil degradation is a pressing ecological concern and a serious threat to sustainable food production. Past management of agroecosystems has substantially degraded and reduced the quality of soils worldwide. For example, mechanical cultivation and continuous production of row crops has resulted in a physical loss of soil and large decreases in SOM..$^{56}$ Inventories of soil productive capacity have found human-induced soil degradation on nearly $40 \%$ of the world's agricultural land. ${ }^{56}$

Scientific monitoring of soil quality is essential to assessing the sustainability of agricultural systems..$^{57}$ Although there are varying methods for measuring soil quality, soil biological properties and soil organisms are of great importance. This is particularly true in organic agriculture, because most nutrients are derived from soil organisms' microbial decomposition of SOM. ${ }^{57}$ Soil organisms meet many of the criteria for useful indicators of sustainable land management: they (1) respond sensitively to land management practices and climate; (2) are correlated with beneficial soil and ecosystem functions, including water storage, decomposition and nutrient cycling, detoxification, and suppression of noxious and pathogenic organisms; and (3) illustrate the chain of cause and effect that links land management decisions to ultimate productivity and the health of plants and animals. ${ }^{56}$

Although it is established that soil organisms are essential to soil quality, ${ }^{37,56}$ the scientific understanding of soil biodiversity as it relates to soil quality is limited, constrained by the tremendous diversity of soil organisms and technical challenges involved. ${ }^{2,38}$ For example, DNA extraction and other methods used to identify and measure specific soil organisms are not standardized and are therefore problematic. ${ }^{37}$

Compared to physical and chemical soil degradation, little is known about how agricultural practices alter soil biological properties and functioning even though soil degradation includes a decline in biodiversity (soil organisms) and soil carbon and an increase in soil-borne pathogens. ${ }^{2,42}$

Research has shown that diversity of arbuscular mycorrhizal fungi, a dominant microbial group in most soil habitats, may determine the productivity of plant communities. ${ }^{58}$ More recent research indicates that for individual plants, increasing arbuscular mycorrhizal fungi diversity promotes 
plant growth and resistance to pathogens. ${ }^{59}$ Hence, an improved understanding of the spatial distribution and functioning of soil microorganisms is essential to meeting a variety of major challenges faced by human society, including challenges related to the future food supply and mitigation of climate change. ${ }^{60,61}$

\section{Organic Agriculture}

Soil quality is affected by farm management and land use decisions. ${ }^{2,55}$ Because most arable land on Earth is now under cultivation and agroecosystems cover $40 \%$ of the terrestrial land surface of the Earth, agricultural land management decisions are crucial to future food production. $^{8}$

Organic agriculture is fundamentally different from conventional agriculture because its guiding land management paradigm is based on a systems view. The systems view recognizes the importance of functional relationships and interconnections between biodiversity (plants, soil organisms, insects, fungi, and animals) in an agroecosystem and the environment. In organic systems, land management practices that promote soil biodiversity and soil quality are emphasized and the goal is to maintain a sustainable agricultural system. ${ }^{62}$

Organic farming contributes substantially to future agricultural production by improving soil quality through promotion of better soil structure (aggregates stability and organic matter supply) and soil nutrition (organic matter supply) ${ }^{63}$ Research has found that practices used in organic agriculture (eg, crop rotations and cover crops, organic amendments, composts, and green manure) can improve soil microbial activity and biomass, ${ }^{64}$ increase soil organic carbon, ${ }^{64,65}$ and increase levels of SOM. ${ }^{66}$ Organic farming also contributes to agricultural production through the use of farmyard manure, which fosters natural enemies and other biota (eg, earthworms) needed for enhanced pest control and cycling of nutrients. ${ }^{63}$

SOM is a critical component of the soil habitat: by providing resources in the form of nutrients to plants, it often constitutes hotspots of soil activity and is fundamental in maintaining fertile and productive soils. ${ }^{37} \mathrm{SOM}$ as humus (see Table 1) - the main driver of soil quality and fertility—can only be produced by the diversity of life that exists in soils. It cannot be manmade. ${ }^{37}$ Humus is an important buffer that helps reduce fluctuations in soil acidity and nutrient availability. Researchers have reported higher levels of soil fertility and greater biodiversity in organic versus conventional agricultural systems. ${ }^{57}$ Soils under organic management have increased SOM and biomass, which (1) retains significantly more rainwater and nutrients due to the sponge-like properties of organic matter, ${ }^{66-68}$ (2) enhances soil structure and fertility, and (3) results in less soil erosion. ${ }^{66,69,70}$ 


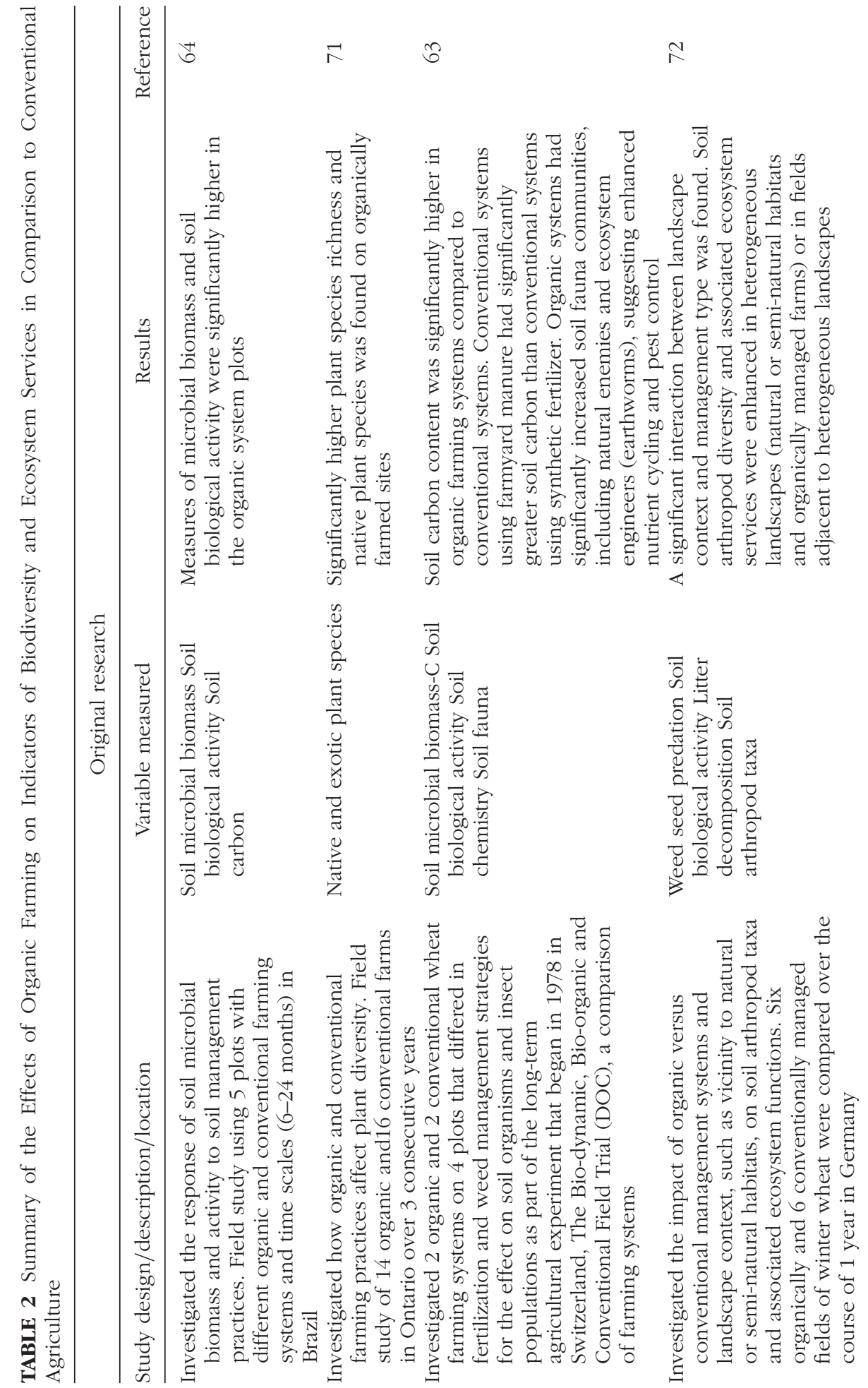




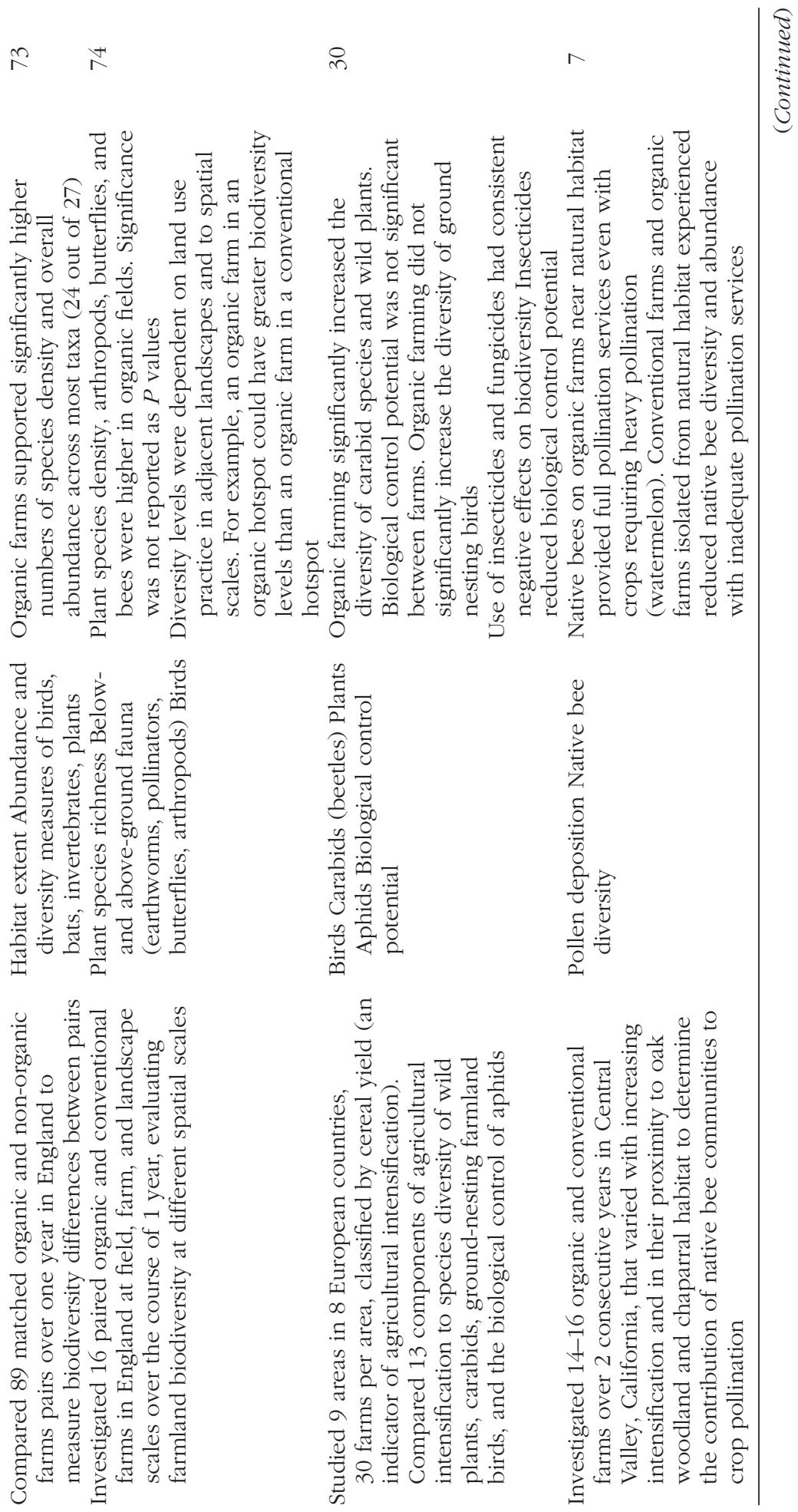




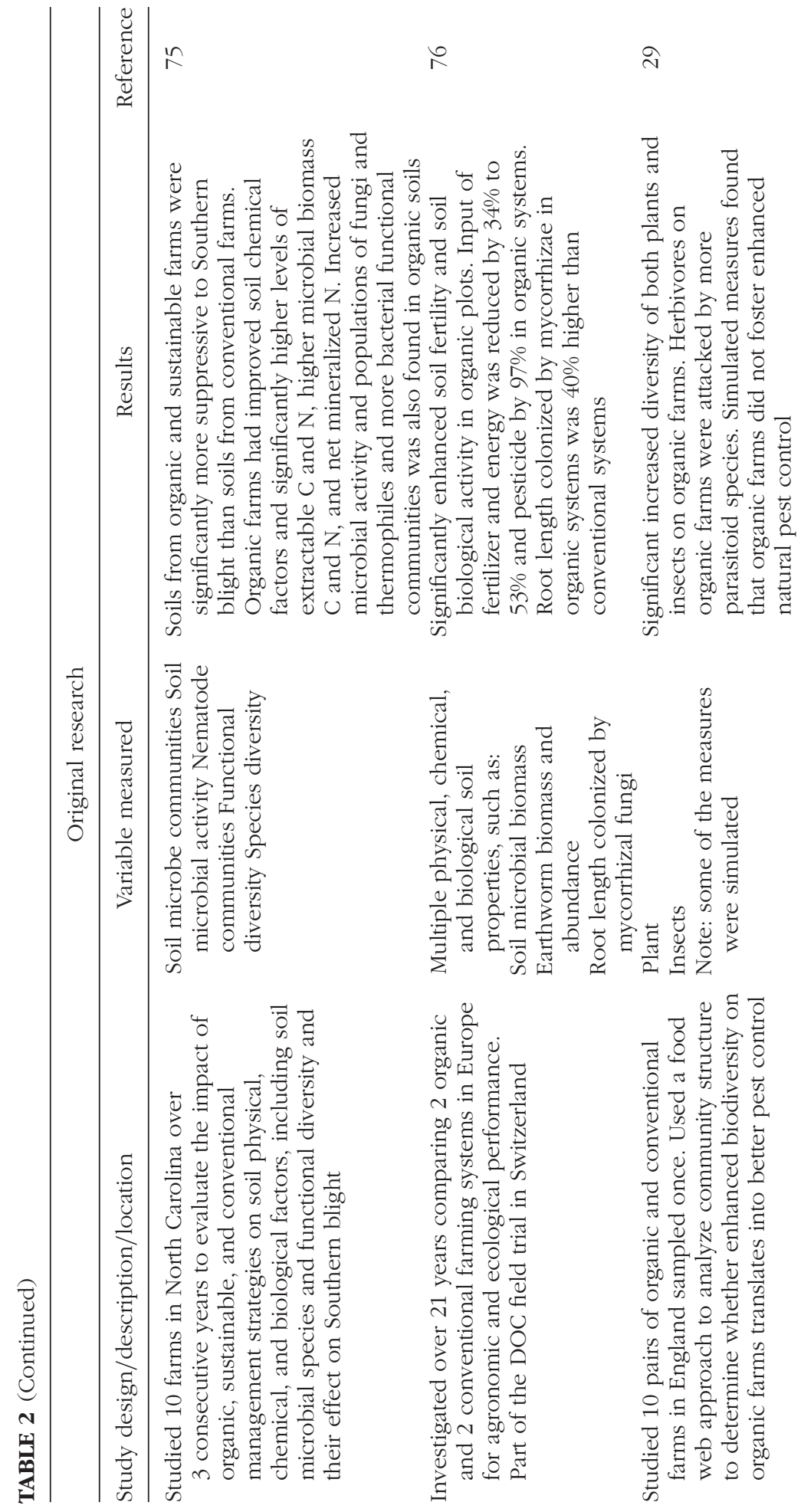


$\hat{N}$

$\stackrel{\infty}{\wedge}$

$\curvearrowright$

$\infty$

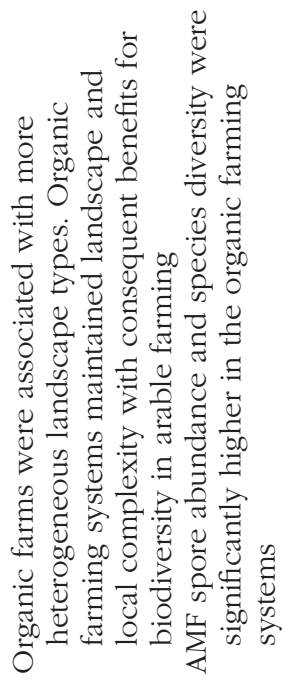

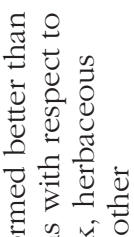

हैं क्षै

蓉司

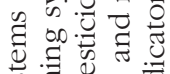

क है

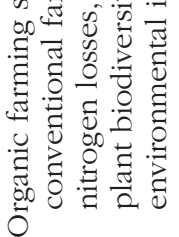

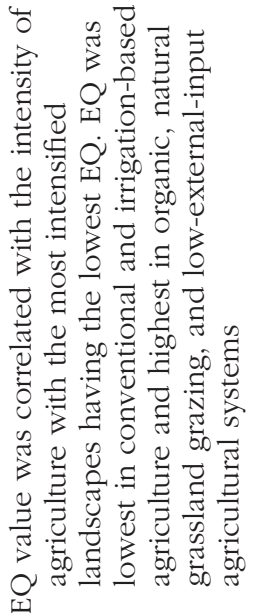

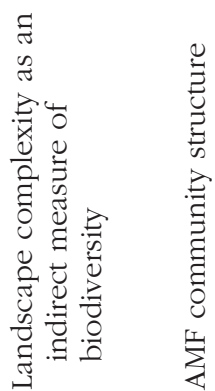

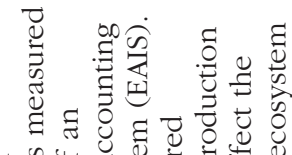

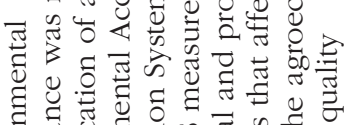

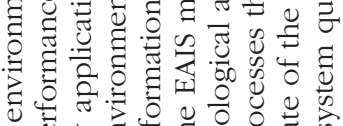

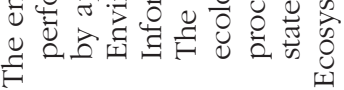

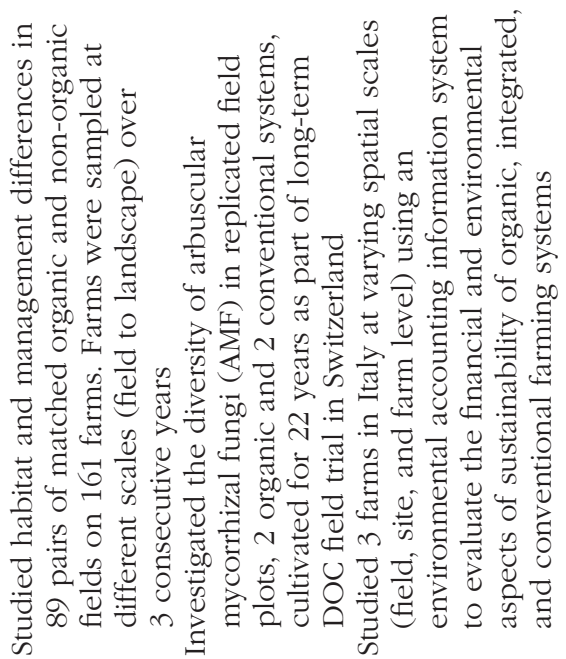

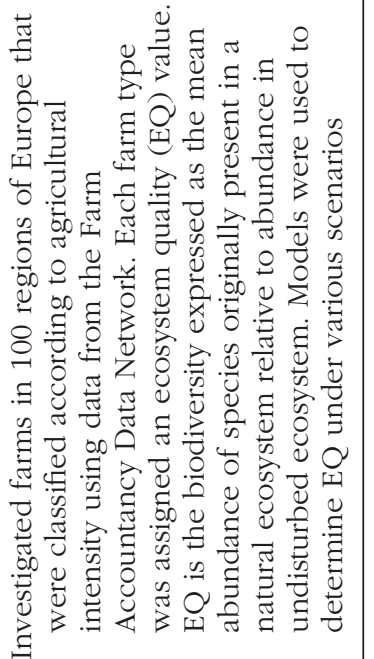




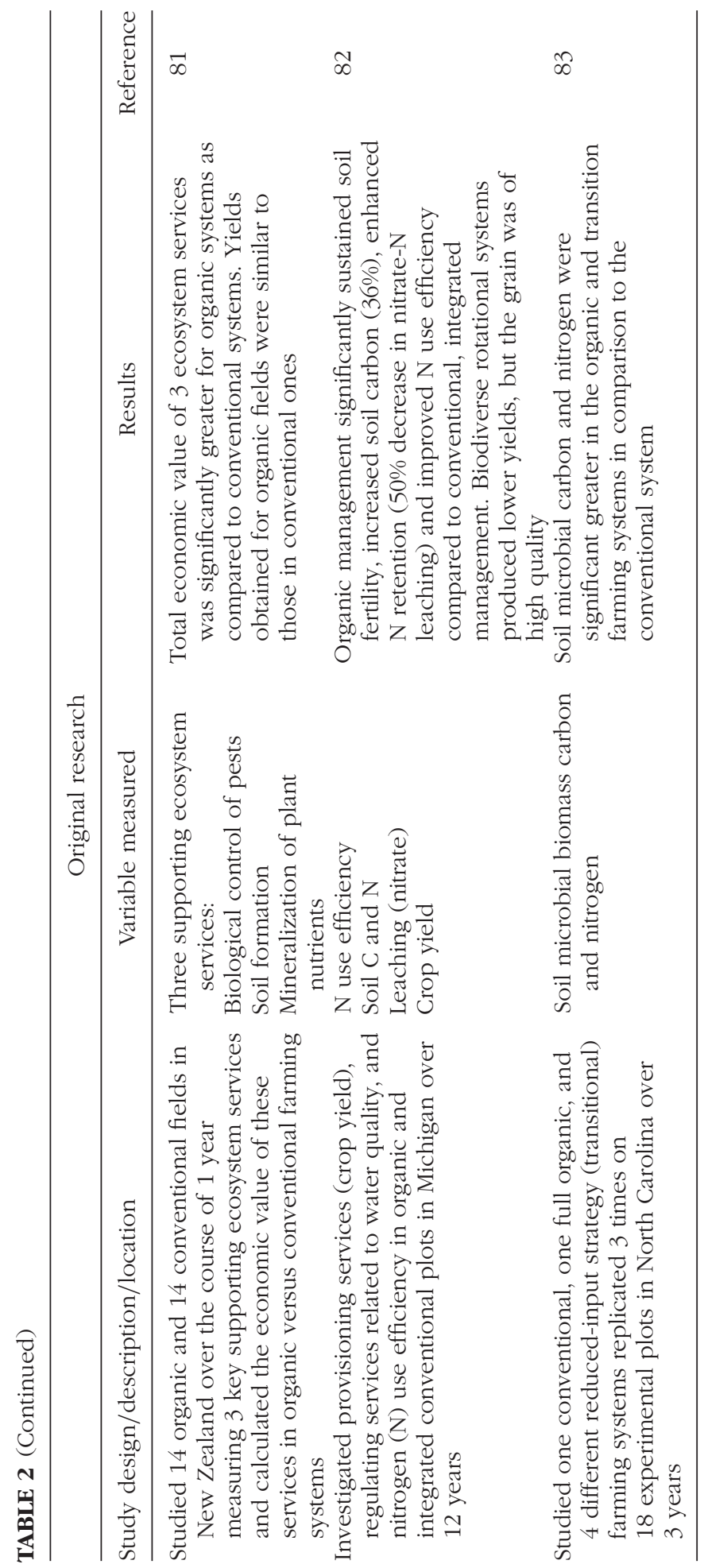


A recent comprehensive study of organic and conventional strawberry ecosystems suggested that organic production methods resulted in both higher quality soil and higher quality strawberries. ${ }^{68}$ The organically farmed soils were higher in carbon (an indicator of SOM) and nitrogen and had greater microbial biomass and activity and greater functional gene abundance and biodiversity. In addition, the organic strawberries had lower concentrations of phosphorus and potassium; higher concentrations of antioxidants, ascorbic acid, and phenolic compounds; longer shelf life; and greater dry matter content. ${ }^{6}$

\section{METHODS}

A literature review was conducted to answer the question: How do organic agriculture management systems and conventional agriculture management systems differ in regard to their impact on biodiversity and ecosystem services? Articles were identified by searching Agricola, PubMed, and Science Direct databases using the keywords organic agriculture and biodiversity. ${ }^{84,85,86}$ In Science Direct, due to the large number of articles that resulted from this first keyword search, articles were narrowed down by using additional keywords: ecosystem services and species richness and searching within the results. Articles were included if they (1) were published from January 2000 to June 2010 in peer-reviewed journals, (2) compared organically managed farms to conventionally managed farms, and (3) measured biodiversity or ecosystem services between organic and conventional production. In addition to the articles identified in the aforementioned database search, references cited in review and published research articles were reviewed.

Conventional farming systems employ a variety of management practices and no exact meaning exists. For the purpose of this review, conventional systems were defined as those that use external inputs to achieve high yields. Organic production systems were defined as farming systems that employ practices characteristic of organic agriculture such as crop rotation, use of legume-based green manures or manure-based fertilization systems, prohibition of synthetic or soluble mineral fertilizers, and prohibition or reduction in the use of synthetic pesticides.

\section{RESULTS AND DISCUSSION}

Twenty-two articles were found that met the criteria described in the Methods section. Eighteen articles were original research ${ }^{7,29,30,63,64,71-83}$ and four were reviews. ${ }^{39,40,45,87}$ The purpose of all articles was to evaluate how 
organic and conventional agricultural systems differ in regard to their impact on various indicators of biodiversity and ecosystem services.

The original research identified (see Table 2) evaluated the effect of farming systems on indicators of soil quality, such as soil carbon and microbial biomass; above- and below-ground farm biodiversity, such as soil microbes, predator insect communities, birds, and native plants; and indicators of enhanced ecosystem services, such as pollination of crops by native bees. Summaries of the variables measured and complete research results are listed in Table 2. All articles identified in this review reported a significant increase in at least one variable that indicated enhanced biodiversity and/or ecosystem service on sites farmed using an organic farming system compared to sites farmed using a conventional farming system.

Bengtsson and colleagues ${ }^{40}$ conducted a review, using a meta-analysis of 42 studies published before December 2002, that analyzed the effects of organic farming (versus conventional) on species richness and abundance. Species richness was 30\% higher on organic farms, but results were highly variable between studies and organism groups. In 2005, Hole and colleagues $^{39}$ reviewed the impact on biodiversity of organic versus conventional farming in 76 studies. Comparing the effect of farming system on individual taxon, Hole and colleagues found that organic farming systems fostered greater species abundance and/or richness in 66 taxa, 25 had neutral or mixed outcomes, only 8 taxa showed a negative outcome.

In 2008, Letourneau and Bothwell ${ }^{87}$ performed a review of the literature to assess the evidence for enhanced insect pest control as a consequence of greater biodiversity on organic farms. The authors argued that although biodiversity is clearly enhanced on organic farms compared to conventional farms in most studies, there was not enough research that measured how the enhanced biodiversity affects pest control and yield. The authors urged ecologists to clarify the links between biodiversity and ecosystem services.

A meta-analysis of more than 100 studies from Brazil in $2009^{45}$ measured microbial biomass and biological activity in soils under various soil management practices, including organic farming. The majority of studies reviewed on organic agriculture indicated that organic agriculture improved soil quality by increasing soil microbial biomass and biological activity probably as a result of organic manure amendments and removal of agrochemicals application. The majority of studies showed that no-till, rotated pastures, permanent organic farming, and crop rotations improved soil quality, whereas overgrazing, agrochemicals, and burning disturbed soil microbial communities. Similar to the conclusions of Letourneau and Bothwell, ${ }^{87}$ these authors found that the direct relationships between biodiversity and ecosystem services were unclear and that more research was needed to evaluate how enhanced biodiversity on organic farms affected ecosystem services. 


\section{Soil Quality and Soil Biodiversity}

As discussed previously, SOM is an essential component of soil and critical to maintaining soil quality. Soil microbial biomass carbon (microbial biomass-C) is a measure of the living portion of SOM. Soil microbes perform numerous processes vital to soil quality, including carbon cycling, nutrient cycling, solubilization of nutrients, and biological control of plant pathogens. ${ }^{45,64}$ One of the most important services provided by soil is the breakdown of SOM by soil microorganisms. ${ }^{55}$ Decomposition of SOM is fundamental to soil quality because it provides resources in the form of nutrients that are required for plant growth. ${ }^{37}$ Six of the articles in this review measured variables associated with SOM decomposition, such as soil microbial biomass-C, soil biological activity, and litter decomposition. ${ }^{63,64,75,76,82,83}$ All found a significant increase in at least one variable associated with enhanced SOM and soil quality in organic production systems compared to conventional.

\section{Biological Pest Control and Pollination Services}

Ninety-nine percent of agricultural pest populations and diseases are controlled by their natural enemies-predators, parasites, and pathogens. ${ }^{81}$ Three studies reviewed showed significant enhancement in indicators of biological pest control in organic systems. ${ }^{63,72,75}$ Geiger and colleagues ${ }^{30}$ did not find a significant difference in biological control potential between farms but did find reduced potential with insecticide use. Macfadyen and colleagues ${ }^{29}$ found significantly increased insect diversity on organic farms, but simulated measures did not find enhanced pest control.

Three studies showed that pest control relationships in the food web depend on general soil biodiversity and that natural pest control is enhanced in biodiverse agroecosystems. ${ }^{29,72,75}$ Deikötter and colleagues ${ }^{72}$ found that biological pest control was enhanced and natural enemy populations were higher in complex landscapes versus simple landscapes. Native landscapes are naturally complex. Organic farming, which includes more diverse crops and frequent crop rotations, also results in complex landscapes. ${ }^{72}$ A recent review $^{87}$ has also indicated that non-crop habitats can be a source of natural enemies for farmlands. Birkhofer and colleagues ${ }^{63}$ showed that long-term organic farming and the application of farmyard manure promoted soil quality and microbial biomass and fostered natural enemies and earthworms, suggesting enhanced nutrient cycling and pest control.

Pollinating animals, particularly bees, are essential for $15 \%$ to $30 \%$ of all food production and valued at $\$ 5$ to $\$ 14$ billion per year in the United States. ${ }^{7}$ Kremen and colleagues ${ }^{7}$ found that on organic farms near native habitat native bees could provide full pollination services. However, all conventional farms and the organic farms isolated from natural habitat experienced 
greatly reduced diversity and abundance of native bees with insufficient pollination services.

\section{Limitations}

Although it is clear that organic agriculture increases biodiversity especially when compared to conventional agriculture, ${ }^{39,40,45,87}$ the direct link to specific ecosystem services has been harder to tease out. ${ }^{37}$ For example, though it is known that microbes are needed for SOM formation, the exact microbial species and mechanisms involved is still unclear. ${ }^{37}$ Similarly, a 2008 review $^{87}$ found that the effect of biodiversity on insect pest control on organic farms has not been fully tested and concluded that more research was needed to delineate the steps involved.

A recently published meta-analysis helps answer the aforementioned research gaps. ${ }^{88}$ In farmlands, pest outbreaks are often the result of altered food web structure and communities dominated by a few common species. ${ }^{88}$ Crowder and colleagues ${ }^{88}$ found high species evenness (the relative abundance of species) of above- and below-ground natural pest enemies in organic potato fields, which resulted in larger plants and decreased pest outbreaks. In contrast, pest densities were high and plants were smaller when pest species evenness was disrupted, as is common in conventional agriculture. Although the specific mechanism by which organic agriculture fosters greater evenness remains unclear, the prohibited use of broad-spectrum pesticides, used in conventional agriculture, may be a factor. Broad-spectrum pesticides kill many species of pests, including beneficial predators. ${ }^{88}$ These researchers noted that evenness may promote resilience to a disturbance by ensuring sufficient densities in key functional roles, which is analogous to the "insurance effect" seen in the species richness literature. ${ }^{88}$ This is an important finding because reduced species richness and evenness can result in reduced ecosystem functioning and services. ${ }^{31}$ Because this meta-analysis was published only after the above-noted literature review was completed, its results were not included in Table 2.

\section{CONCLUSIONS}

US organic agriculture certification is likely the most well-established food standard related to ecosystem concerns in the United States. Organic production regulations have been administered and enforced by the United States Department of Agriculture (USDA) National Organic Program (NOP) ${ }^{46}$ since 2002 when rules from the Organic Foods Production Act of $1990^{47}$ were promulgated. The NOP's mission is to facilitate trade and ensure the integrity of organic agricultural products by consistently implementing organic standards and enforcing compliance with the regulations throughout the world. ${ }^{89}$ 
The resulting US program focuses on health and environmental issues but generally does not address labor, social, economic, or community welfare goals, which are often cited in international standards (see International Federation of Organic Agriculture Movement [IFOAM] definition Table 1). Additionally, organic producers themselves often cite other principles of organic farming, such as animal welfare, as important. ${ }^{90}$

Despite the current distressed state of the economy, US sales of organic food products continue to grow. A recent industry survey by the Organic Trade Association found that organic food sales grew by 5.2\% (compared to a general food sales increase of $1.6 \%$ ) in 2009 , reaching $\$ 24.8$ billion. $^{62}$ To meet this increasing demand, producers have increased acreage, but at 4.6 million acres in 2008 this acreage is still less than 1\% of the total agricultural acreage and not enough to meet demand. ${ }^{62}$ This low level of adoption of organic farming in the United States may be attributed to several factors, including lack of technical assistance through research and extension, resources, and capital to assist farmers with production and marketing of organically produced foods. ${ }^{48}$ This is likely a result of the poor public investment through policy in organic agriculture, from research to payments for programs. However, the Food, Conservation, and Energy Act of 2008 (2008 Farm Bill) directed the USDA to make major increases in support of organic producers through (1) help for producer certification costs, (2) access to federal credit, (3) trade assistance, (4) crop insurance programs, (5) access to conservation programs, and (6) funding for research on production, marketing, and data collection. ${ }^{91}$ For example, in September 2010 the USDA announced that the Organic Certification Cost Share Program would pay up to $75 \%$ of certification costs for organic farms. ${ }^{92}$ To help organic farmers with crop insurance, in August 2010 the USDA released reports outlining improvements to crop insurance programs for organic farmers. ${ }^{93}$ The USDA's Natural Resources Conservation Service (NRCS) implemented a new conservation initiative, the Environmental Quality Incentive Program (EQIP) Organic Initiative, aimed at assisting organic and transitional farmers by making conservation practices related to organic production and transition to organic production eligible for payments under the EQIP conservation program. ${ }^{48}$ The program enrolled over 300000 acres in 2009, obligating over $\$ 36$ million in conservation assistance. Additionally, organic producers can participate in the Integrated Organic and Water Quality Program, ${ }^{94}$ the Conservation Stewardship Program (CSP), and the Conservation Innovation Grants Program. ${ }^{95}$ Organic research dollars increased significantly in the 2008 Farm Bill through the Organic Agriculture Research and Extension Initiative (OREI), administered by the USDA's National Institute of Food and Agriculture, which devoted \$19 million in 2010 to fund projects that enhance the ability of producers and processors to grow and market highquality organic agricultural products. ${ }^{94}$ This funding is part of the Know Your Farmer, Know Your Food Initiative led by USDA Deputy Secretary Merrigan. 


\section{Organic Farming Systems and Ecosystems Services}

Environmental and health benefits (ecosystem services) from organic production practices, including but not limited to improved water quality, soil biodiversity, and increased carbon sequestration, are often indirect and undervalued. As a result, producers are not compensated for their efforts. ${ }^{2}$ However, the 2008 Farm Bill included a provision to facilitate the participation of farmers and landowners in environmental services markets (eg, carbon markets, see Table 1$)^{96}$ by requiring the USDA to establish technical guidelines for measurements, reporting and data registry of ecosystem services. ${ }^{97}$

Studies show that establishing a successful payment for ecosystem services (PES) is a complex undertaking that requires not only scientific understanding but also consideration of social, economic, political, institutional, and power relationships. ${ }^{2}$ For PES programs to work, buyers want documentation and assurance that they are getting what they paid for and that sellers (ie, farmers and ranchers) are getting a fair price for what they produce.

\section{Implications for Research}

Drinkwater ${ }^{90}$ argued that 3 fundamental characteristics of organic agriculture have important implications for research. First, organic agriculture has evolved through a grassroots-based, farmer-dominated process. Second, organic farming systems apply an integrated-systems-based management strategy. And third, the goals of farmers practicing organic agriculture are multidimensional and go beyond maximizing yield or economic return (eg, soil quality or health). Farmer-participatory programs for promoting soil health have successfully included earthworm abundance as an indicator of soil quality and health. ${ }^{90}$ Finally, as observed elsewhere, ${ }^{37,40}$ future studies comparing different aspects of organic and conventional agricultural production need to conduct such comparisons in a more integrated fashion, as demonstrated by Reganold and colleagues. ${ }^{68}$

\section{Roles for Food and Nutrition Professionals}

The platform of a sustainable food system rests on food production. Eighteen original research articles and 4 reviews identified in this article support the view that organic agriculture holds much promise for maintaining soil quality, preserving biodiversity, and helping to ensure sustainable food production. This review underscores the importance of and need for further research on biodiversity, soil quality, and sustainable agriculture to future food production. The findings presented also highlight the need for dietitians to consider ecology and farming systems when making food recommendations to the public. 
Food and nutrition professionals can have significant roles in organic food systems through education, research, policy, and direct participation. This supports the American Dietetic Association's (ADA) position "to encourage environmentally responsible practices that conserve natural resources, minimize the quantity of waste generated, and support the ecological sustainability of the food system." Specific roles for food and nutrition professionals are outlined in this position statement in addition to a report produced for the ADA House of Delegates on sustainable food systems, of which organic production is an important segment. ${ }^{93\left(\mathrm{p}^{1033)} \text { For example, roles }\right.}$ for food and nutrition professionals can include educating eaters on organic production's health and ecological benefits, researching organic production's influence on the eating behaviors of individuals, research on organic production's influence on human or ecosystem health, and influencing food policy through work on food policy councils to support through participation by the purchase of organic foods in institutional settings. Regardless of the area of dietetic practice, food and nutrition professionals are involved in the food system and in turn in organic production. The roles are numerous, as outlined in these ADA resources, whether professional or personal.

\section{REFERENCES}

1. Shoemaker R, McGranahan D, McBride W. Agricultural and rural communities are resilient to high energy costs. Amber Waves. 2006;4(2):16-21.

2. Committee on Twenty-First Century Systems Agriculture, National Research Council. Toward Sustainable Agricultural Systems in the 21st Century. Washington, DC: National Academies Press; 2010.

3. Horrigan L, Lawrence RS, Walker P. How sustainable agriculture can address the environmental and human health harms of industrial agriculture. Environ Health Perspect. 2002;110:445-456.

4. Pimentel D, Hepperly P, Hanson J, Douds D, Seidel R. Environmental, energetic, and economic comparisons of organic and conventional farming systems. Bioscience. 2005;55:573-582.

5. Harmon AH, Gerald BL. Position of the American Dietetic Association: food and nutrition professionals can implement practices to conserve natural resources and support ecological sustainability. J Am Diet Assoc. 2007;107:1033-1043.

6. Hayes TB, Khoury V, Narayan A, et al. Atrazine induces complete feminization and chemical castration in male African clawed frogs (Xenopus laevis). Proc Natl Acad Sci USA. 2010;107:4612-4617.

7. Kremen C, Williams NM, Thorp RW. Crop pollination from native bees at risk from agricultural intensification. Proc Natl Acad Sci USA. 2002;99:16812-16816.

8. Power AG, O'Rourke M, Drinkwater LE. Human-dominated systems: agroecosystems. In: Levin SA, ed. The Princeton Guide to Ecology. Princeton, NJ: Princeton University Press; 2009:597-605. 
9. Matson PA, Parton WJ, Power AG, Swift MJ. Agricultural intensification and ecosystem properties. Science. 1997;277:504-509.

10. Hillebrand H, Bennett DM, Cadotte MW. Consequences of dominance: review of evenness effects on local and regional ecosystem processes. Ecology. 2008;89:1510-1520.

11. President's Cancer Panel. Reducing Environmental Cancer Risk: What We Can Do Now. Bethesda, Md: US Department of Health and Human Services, National Institutes of Health, National Cancer Institute; 2010. Available at: http://deainfo.nci.nih.gov/advisory/pcp/annualReports/pcp 08-09rpt/PCP_Report_08-09_508.pdf. Accessed: December 17, 2010.

12. Costello S, Cockburn M, Bronstein J, Zhang X, Ritz B. Parkinson's disease and residential exposure to maneb and paraquat from agricultural applications in the Central Valley of California. Am J Epidemiol. 2009;169:919-926.

13. Marks AR, Harley K, Bradman A, et al. Organophosphate pesticide exposure and attention in young Mexican-American children. Environ Health Perspect. 2010;118:1768-1773.

14. Wright Willis A, Evanoff BA, Lian M, Criswell SR, Racette BA. Geographic and ethnic variation in Parkinson disease: a population-based study of US Medicare beneficiaries. Neuroepidemiology. 2010;34:143-151.

15. Goldner WS, Sandler DP, Yu F, Hoppin JA, Kamel F, LeVan T. Pesticide use and thyroid disease among women in the Agricultural Health Study. Am J Epidemiol. 2010;171:455-464.

16. Harari R, Julvez J, Murata K, et al. Neurobehavioral deficits and increased blood pressure in school-age children prenatally exposed to pesticides. Environ Health Perspect. 2010;118:890-896.

17. Wigle DT, Turner MC, Krewski D. A systemic review and meta-analysis of childhood leukemia and parental occupational pesticide exposure. Environ Health Perspect. 2009;117:1505-1513.

18. Montgomery MP, Kamel F, Saldana TM, Alavanja MCR, Sandler DP. Incident diabetes and pesticide exposure among licensed pesticide applicators: Agricultural Health Study, 1993-2003. Am J Epidemiol. 2008;167:1235-1246.

19. Ward MH, Kilfoy BA, Weyer PJ, Anderson KE, Folsom AR, Cerhan JR. Nitrate intake and risk of thyroid cancer and thyroid disease. Epidemiology. 2010;21:389-395.

20. Waller SA, Paul K, Peterson SE, Hitti JE. Agricultural-related chemical exposures, season of conception, and risk of gastroschisis in Washington State. Am J Obstet Gynecol. 2010;202:412-414.

21. Bouchard MF, Bellinger DC, Wright RO, Weisskopf MG. Attentiondeficit/hyperactivity disorder and urinary metabolites of organophosphate pesticides. Pediatrics. 2010;125:e1270-e1277.

22. Winchester PD, Huskins J, Ying J. Agrichemicals in surface water and birth defects in the United States. Acta Paediatr. 2009;98:664-669.

23. Ochoa-Acuña H, Frankenberger J, Hahn L, Carbajo C. Drinking water herbicide exposure in Indiana and prevalence of small-for-gestational-age and preterm delivery. Environ Health Perspect. 2009;117:1-17. 
24. Mattix KD, Winchester PD, Scherer LR. Incidence of abdominal wall defects is related to surface water atrazine and nitrate levels. J Pediatr Surg. 2007;42: 947-949.

25. Guo JH, Liu XJ, Zhang Y, et al. Significant acidification in major Chinese croplands. Science. 2010;327:1008-1010.

26. Millennium Ecosystem Assessment. Ecosystems and Human Well-Being: A Framework for Assessment. Washington, DC: Island Press; 2005.

27. Reid WV, Mooney HA, Cropper A, et al. Millennium Ecosystem Assessment Synthesis Report. Washington, DC: Island Press; 2005.

28. Firbank LG, Petit S, Smart S, Blain A, Fuller RJ. Assessing the impacts of agricultural intensification on biodiversity: a British perspective. Phil Trans $R$ Soc B. 2008;363:777-787.

29. Macfadyen S, Gibson R, Polaszek A, et al. Do differences in food web structure between organic and conventional farms affect the ecosystem service of pest control? Ecol Lett. 2009;12:229-238.

30. Geiger F, Bengtsson J, Berendse F, et al. Persistent negative effects of pesticides on biodiversity and biological control potential on European farmland. Basic Appl Ecol. 2010;11:97-105.

31. Turnbull LA, Hecto A. How to get even with pests. Nature. 2010;466(1): 36-37.

32. Ecological Society of America. Ecosystems Services: A Primer. Available at: http://www.actionbioscience.org/environment/esa.html. Accessed March 10, 2010.

33. Hooper DU, Chapin FS, Ewel JJ, et al. Effects of biodiversity on ecosystem functioning: a consensus of current knowledge. Jamestown, ND: Northern Prairie Wildlife Research Center; 2005. Available at: http://www.npwrs.usgs. gov/resource/habitat/econsens/index.htm. Accessed May 25, 2010.

34. Altieri M. The ecological role of biodiversity in agroecosystems. Agric Ecosyst Environ. 1999;4:19-31.

35. Cassman KG, Wood S. Cultivated systems. In: Millennium Ecosystem Assessment: Global Ecosystem Assessment Report on Conditions and Trends. A. Balisacan and P. Gardiner, Eds. Washington, DC: Island Press; 2005:741-789.

36. Naeem S. Biodiversity, ecosystem functioning, and ecosystem services. In: Levin SA, ed. The Princeton Guide to Ecology. Princeton, NJ: Princeton University Press; 2009:584-590.

37. Turbe A, De Toni A, Benito P, et al. Soil Biodiversity: Functions, Threats and Tools for Policy Makers. Paris, France: Bio Intelligence Service, Institut de Recherche pour le Developpement, and Netherlands Institute of Ecology; 2010. Available at: http://ec.europa.eu/environment/soil/pdf/biodiversity_report.pdf. Accessed May 10, 2010.

38. Hillel D, Rosenzweig C. Biodiversity and food production. In: Chivian E, Bernstein A, eds. Sustaining Life, How Human Health Depends on Biodiversity. New York, NY: Oxford Press; 2008. pp. 325-381.

39. Hole DG, Perkins AJ, Wilson JD, Alexander IH, Grice PV, Evans AD. Does organic farming benefit biodiversity? Biol Conserv. 2005;122:113-130.

40. Bengtsson J, Ahnstrom J, Weibull A. The effects of organic agriculture on biodiversity and abundance: a meta-analysis. J Appl Ecol. 2005;42:261-269. 
41. Levin SA, ed. Glossary. In: The Princeton Guide to Ecology. Princeton, NJ: Princeton University Press; 2009:789.

42. Lal R. Soil carbon sequestration impacts on global climate change and food security. Science. 2004;304:1623-1627.

43. Food and Agriculture Organization of the United Nations. Agricultural Biodiversity in FAO. Rome, Italy: Food and Agriculture Organization, 2008.

44. Financial Times Lexicon. Carbon market. Available at: http://lexicon.ft.com/ term.asp?t=carbon-market. Accessed September 29, 2010.

45. Kaschuk G, Alberton O, Hungria M. Three decades of soil microbial biomass studies in Brazilian ecosystems: Lessons learned about soil quality and indications for improving sustainability. Soil Biol Biochem. 2010;42:1-13.

46. Electronic Code of Federal Regulations website (e-CFR). Title 7, Part 205, National Organic Program (current as of November $2^{\text {nd }}$ 2010). Available at: http://ecfr.gpoaccess.gov/cgi/t/text/text-idx?c=ecfr\&tpl=/ecfrbrowse/Title07/ 7cfr205_main_02.tpl. Accessed November 3, 2010.

47. Legal Information Institute, Cornell University Law School. U.S. Code, Title 7, Chapter 94, II 6501-6522. Available at: http://www.law.cornell.edu/uscode/ html/uscode07/usc_sup_01_7_10_94.html. Accessed on November $3^{\text {rd }} 2010$.

48. Greene C, Slattery E, McBride WD. America's organic farmers face issues and opportunities. Amber Waves. 2010;8(2):34-39.

49. World Health Organization, Food and Agriculture Organization of the United Nations (FAO). Codex Guidelines-Organic Agriculture. 3rd ed. Rome, Italy: World Health Organization, Food and Agriculture Organization of the United Nations; 2007. Available at: http://ftp://ftp.fao.org/codex/Publications/ Booklets/Organics/organic_2007e.pdf. Accessed November 3, 2010.

50. International Federation of Organic Agriculture Movement. Definition of organic agriculture. Available at: http://www.ifoam.org/growing_organic/ definitions/doa/index.html. Accessed October 15, 2010.

51. Lal R. Degradation and resilience of soils. Phil Trans $R$ Soc Lond. 1997;352:997-1010.

52. Soil Science Society of America. Glossary of soil science terms. Available at: https://www.soils.org/publications/soils-glossary\#. Accessed January 6, 2011.

53. Natural Resources Conservation Service. Soil quality. Available at: http:// soils.usda.gov/technical/handbook/contents/part624.html. Accessed January 6, 2011.

54. Brundtland GH. Our Common Future. New York, NY: Oxford University Press; 1987.

55. Sandu S, Wratten S, Cullen R. Organic agriculture and ecosystem services. Environ Sci Policy. 2010;13(1):1-7.

56. Doran JW, Zeiss MR. Soil health and sustainability: managing the biotic component of soil quality. Appl Soil Ecol. 2000;14:3-11.

57. Franzlubbers AJ, Haney RL. Assessing soil quality in organic agriculture [The Organic Center Web site]. Available at: http://www.organic-center.org/ reportfiles/Soil_Quality_Report.pdf. Accessed January 17, 2011.

58. van der Heijden MGA, Klironomos JN, Ursic M, et al. Mycorrhizal fungal diversity determines plant biodiversity, ecosystem variability and productivity. Nature. 1998;396:69-72. 
59. Maherali $\mathrm{H}$, Klironomos JN. Influence of phylogeny on fungal community assembly and ecosystem functioning. Science. 2007;316:1746-1748.

60. Prosser JI, Bohannan BJM, Curtis TP, et al. Essay-the role of ecological theory in microbial ecology. Nat Rev Microbiol. 2007;5:384-392.

61. Van der Gast, Gosling P, Tiwari B, Bending GD. Spatial scaling of arbuscular mycorrhizal fungal diversity is affected by farming practice. Environ Microbiol. 2010:1-9.

62. Organic Trade Association. Organic Food Facts. Available at: http://www.ota. com/organic/mt/food.html. Accessed February 14, 2011.

63. Birkhofer K, Bezeer TM, Bloem J, et al. Long-term organic farming fosters below and aboveground biota: Implications for soil quality, biological control and productivity. Soil Biol Biochem. 2008;40:2297-2308.

64. Araújo ASF, Santos VB, Monteiro RTR. Responses of soil microbial biomass and activity for practices of organic and conventional farming systems in Piauí state, Brazil. Eur J Soil Biol. 2008;44:225-230.

65. Muller-Lindenlauf M. Organic Agriculture and Carbon Sequestration. Rome, Italy: Natural Resources Management and Environment Department, Food and Agriculture Organization of the United Nations; 2009. Available at: http://ftp:// ftp.fao.org/docrep/fao/012/ak998e/ak998e00.pdf. Accessed January 15, 2010.

66. Niggli U, FlieBbach A, Hepperly P, Scialabba N. Low Greenhouse Gas Agriculture: Mitigation and Adaptation Potential of Sustainable Farming Systems. Rome, Italy: Food and Agriculture Organization of the United Nations; 2009. Available at: http://ftp://ftp.fao.org/docrep/fao/010/ai781e/ai781e00.pdf. Accessed June 29, 2009.

67. Weil RR, Magdoff F. Significance of soil organic matter to soil quality and health. In: Magdoff F, Weill RR, eds. Soil Organic Matter in Sustainable Agriculture. Boca Raton, Fla: CRC Press; 2004:1-43.

68. Reganold JP, Andrews PK, Reeve JR, et al. Fruit and soil quality of organic and conventional strawberry agroecosystems. PLoS One. 2010;5(9):1-4.

69. Reganold JP, Elliot LF, Unger YL. Long-term effects of organic and conventional farming on soil erosion. Nature.1987;330:370-372.

70. Siegrist S, Staub D, Pfiffner L, Mäder P. Does organic agriculture reduce soil erodibility? The results of a long-term field study on loess in Switzerland. Agric Ecosyst Environ. 1998;69:253-264.

71. Boutin C, Baril A, Martin PA. Plant diversity in crop fields and woody hedgerows of organic and conventional farms in contrasting landscapes. Agric Ecosyst Environ. 2007;123:185-193.

72. Diekötter T, Wamser S, Wolters V, Birkhofer K. Landscape and management effects on structure and function of soil arthropod communities in winter wheat. Agric Ecosyst Environ. 2008;137:108-112.

73. Fuller RJ, Norton LR, Feber RE, et al. Benefits of organic farming to biodiversity vary among taxa. Biol Lett. 2005;1:431-434.

74. Gabriel D, Sait S, Hodgson J, Schmutz U, Kunin WE, Benton TG. Scale matters: the impact of organic farming on biodiversity at different spatial scales. Ecol Lett. 2010. pp. 1-12.

75. Liu B, Tu C, Hu S, Gumpertz M, Ristaino JB. Effect of organic, sustainable, and conventional management strategies in grower fields on soil physical, chemical, 
and biological factors and the incidence of Southern blight. Appl Soil Ecol. 2007;37:202-214.

76. Mader P, FlieBback A, Dubois D, Gunst L, Fried P, Niggli U. Soil fertility and biodiversity in organic farming. Science. 2002;296:1694-1697.

77. Norton L, Johnson P, Joys A, et al. Consequences of organic and non-organic farming practices for field, farm and landscape complexity. Agric Ecosyst Environ. 2009;129:221-227.

78. Oehl F, Sieverding E, Mäder P, et al. Impact of long-term conventional and organic farming on the diversity of arbuscular mycorrhizal fungi. Oecologia. 2004; 138:574-583.

79. Pacini C, Wossink A, Giesen G, Vazzana C, Huirne R. Evaluation of sustainability of organic, integrated and conventional farming systems: a farm and field-scale analysis. Agric Ecosyst Environ. 2003;95:273-288.

80. Reidsma P, Tekelenburg T, van den Berg M, Alkemade R. Impacts of landuse change on biodiversity: An assessment of agricultural biodiversity in the European Union. Agric Ecosyst Environ. 2006;114:86-102.

81. Sandhu H, Wratten S, Cullen R. The role of supporting ecosystem services in conventional and organic arable farmland. Ecol Complex. 2010;7:302-310.

82. Snapp S, Gentry LE, Harwood R. 2010. Management intensity-not biodiversity-the driver of ecosystem services in a long-term row crop experiment. Agric Ecosyst Environ, 2010;138:242-248.

83. Tu C, Louws FJ, Creamer NG, et al. Responses of soil microbial biomass and N availability to transition strategies from conventional to organic farming systems. Agric Ecosyst Environ. 2006;113:206-215.

84. United States Department of Agriculture, National Agricultural Library. AGRICOLA website. Available at: http://agricola.nal.usda.gov/. Accessed June 8, 2010.

85. US National Library of Medicine, National Institutes of Health. PubMed website. Available at: http://www.ncbi.nlm.nih.gov/pubmed/. Accessed June 10, 2010.

86. SciVerse. Science Direct website. Available at: http://www.sciencedirect.com/. Accessed June 8, 2010.

87. Letourneau DK, Bothwell, SG. Comparison of organic and conventional farms: challenging ecologists to make biodiversity functional. Front Ecol Environ. 2008;6:430-438.

88. Crowder DW, Northfield TD, Strand MR, Snyder WE. Organic agriculture promotes evenness and natural pest control. Nature. 2010;466:109-112.

89. US Department of Agriculture, Agricultural Marketing Service National Organic Program. Organic Integrity from Farm to Table, Consumers Trust the Organic Label, Strategic Plan 2010-2012. Available at: http://www.ams.usda.gov/ AMSv1.0/getfile?dDocName=STELPRDC5086491\&acct=nopgeninfo/. Accessed September 13, 2010.

90. Drinkwater L. Ecological knowledge: foundation for sustainable organic agriculture. In: Francis C, ed. Organic Farming: The Ecological System. Madison, Wis: American Society of Agronomy, Crop Science Society of America, and Soil Science Society of America; 2009. pp. 19-47.

91. US Department of Agriculture, Economic Research Service. The Food, Conservation, and Energy Act of 2008. Pub L No. 110-246. Available 
at: http://www.ers.usda.gov/FarmBill/2008/Titles/TitleIIConservation.htm? referer $=$ www.clickfind.com.au. Accessed October 11, 2010.

92. US Department of Agriculture, Agricultural Marketing Service. Notice of 2010 National Organic Certification Cost-Share Program. Fed Regist. 2010;75:54590. Available at: http://www.ams.usda.gov/AMSv1.0/getfile?dDoc Name=STELPRDC5086487\&acct=noprulemaking. Accessed October 11, 2010.

93. US Department of Agriculture. The USDA Risk Management Agency releases reports outlining improvements to crop insurance programs for organic crops. News release No. 0431.1. Available at: http://www.usda.gov/wps/portal/ usda/usdahome?contentidonly $=$ true\&contentid=2010/08/0431.xml. Accessed October 11, 2010.

94. US Department of Agriculture. Agriculture Deputy Secretary Merrigan announces \$19 million in organic research, education, and extension grants. News Release No. 0539.09. Available at: http://www.usda.gov/wps/portal/

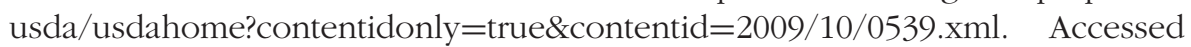
October 11, 2010.

95. USDA Economic Research Service. 2008 Farm Bill Side by Side. Available at: http://www.ers.usda.gov/FarmBill/2008/. Accessed October 11, 2010.

96. The National Agriculture Law Center. Congressional Research Service Report. Provisions Supporting Ecosystem Services Markets in US Farm Bill Legislation. Available at: http://www.nationalaglawcenter.org/assets/crs/ RL34042.pdf. Accessed October 11, 2010.

97. USDA Economic Research Service. The Food, Conservation, and Energy Act of 2008. Pub L No. 110-246, \$2709, Environmental Services Markets. Available at: http://www.ers.usda.gov/FarmBill/2008/Titles/TitleIIConservation.htm? referer $=$ www.clickfind.com.au. Accessed October 11, 2010.

98. ADA Sustainable Food Systems Task Force. Healthy Land, Healthy People: Building a Better Understanding of Sustainable Food Systems for Food and Nutrition Professionals. Chicago, Ill: American Dietetic Association; 2007. 